\title{
Perspectives for the use of plant extracts to control the cattle tick Rhipicephalus (Boophilus) microplus
}

Perspectivas para o uso de extratos de plantas para o controle do carrapato de bovinos Rhipicephalus (Boophilus) microplus

Lígia Miranda Ferreira Borges ${ }^{1 *}$; Lorena Alessandra Dias de Sousa²; Carolina da Silva Barbosa²

${ }^{1}$ Setor de Parasitologia, Instituto de Patologia Tropical e Saúde Pública, Universidade Federal de Goiás - UFG

${ }^{2}$ Escola de Veterinária, Universidade Federal de Goiás - UFG

Received December 1, 2010

Accepted January 27, 2011

\begin{abstract}
The evolution of resistance of Rhipicephalus (Boophilus) microplus to synthetic acaricides has given rise to the need for new scientific investigations on alternative ways to control this tick. In this regard, various studies on plants have been developed in an attempt to find extracts with acaricidal properties. Evaluations on plant extracts for controlling $R$. (B.) microplus have grown intensely over the last decade. There are many advantages from using plant extracts: for example, they can be used in organic cattle farming or even replace synthetic acaricides and they are associated with lower environmental and food contamination, slower development of resistance and lower toxicity to animals and humans. In vitro studies on plant extracts have shown promising results, but most of these extracts have not been tested on animals to validate their use. Difficulties in preparing proper formulations, differences in the chemical composition of plants of the same species due to extrinsic and intrinsic factors and sparse information on active acaricide compounds are hindrances that need to be addressed in order to enable progress within this scientific field.
\end{abstract}

Keywords: Phytotherapy, cattle tick, Rhipicephalus (Boophilus) microplus, in vitro bioassays, in vivo bioassays.

\section{Resumo}

A evolução da resistência do Rhipicephalus (Boophilus) microplus aos acaricidas sintéticos tem impulsionado novas investigaçóes científicas sobre métodos alternativos para controlar este carrapato. Considerando isso, vários estudos com plantas têm sido desenvolvidos numa tentativa de encontrar extratos com propriedades acaricidas. Avaliçóes de extratos de plantas para o controle de $R$. (B.) microplus tem sido intensificadas nesta última década. Existem muitas vantagens com o uso de extratos de plantas no controle deste carrapato, como: eles podem ser utilizados na produção orgânica de bovinos, ou mesmo substituir os acaricidas sintéticos, além do mais, estão associados com baixa contaminação ambiental e dos alimentos, desenvolvimento mais lento de resistência e baixa toxicidade para animais e seres humanos. Estudos in vitro de extratos de plantas têm apresentado resultados promissores, mas a maioria destes extratos não têm sido testada em animais para validar estes resultados. Dificuldades para preparar formulaçóes apropriadas, diferenças na composição química de plantas de uma mesma espécie devido a fatores intrínsecos e extrínsecos e informaçôes esparsas.sobre os princípios ativos são entraves que precisam ser solucionados visando o desenvolvimento deste campo de pesquisa.

Palavras-chave: Fitoterapia, carrapato de bovinos, Rhipicephalus (Boophilus) microplus, testes in vitro, testes in vivo.

\footnotetext{
*Corresponding author: Lígia Miranda Ferreira Borges

Setor de Parasitologia, Instituto de Patologia Tropical e Saúde Pública,

Universidade Federal de Goiás - UFG, Rua 235 s/n,

CEP 74001-970, Goiânia - GO, Brazil;

e-mail: borges.ligia@gmail.com
} 


\section{Introduction}

From an economic point of view, Rhipicephalus (Boophilus) microplus (Canestrini 1887) (Acari, Ixodidae) is the main tick in the Neotropical region and one of the most important in the world (WALKER et al., 2003; MARTINS et al., 2006; JONSSON; PIPER, 2007). The principal control method involves the use of synthetic acaricides. However, the development and selection of resistant strains of $R$. (B.) microplus in different parts of the world has made several chemical agents ineffective (FAO, 2004). Moreover, environmental pollution and contamination of meat and milk are associated with this kind of control (SONENSHINE, 1993).

Research on plants for use in tick control has been developed in an attempt to find extracts with acaricidal properties that can be used in association with or even as replacements for synthetic compounds. One advantage from the use of those compounds is that resistance develops slowly because there is usually a mixture of different active agents with different mechanisms of action (BALANDRIN et al., 1985; CHAGAS et al. 2003; OLIVO et al., 2009). Plant based formulations enable expansion of organic agriculture or may even be used as an auxiliary in conventional production systems (VIEIRA; CAVALCANTE, 1999; OLIVO et al., 2009).

The use of phytotherapy in the field of veterinary sciences has been an incremental process. Nevertheless, it needs to be emphasized that investigations on the use of plant extracts to control ticks, especially $R$. (B.) microplus, have become intensified over the last decade, both in Brazil and in other countries. Even though a large number of investigations have proven the acaricide activity of certain plant extracts in the laboratory, follow-up studies are needed with the aim of validating this control strategy.

In this review, the main plants that could be used to control $R$. (B.) microplus, both in vitro and in vivo, and the barriers faced in developing this alternative tick control strategy, will be discussed.

\section{In Vitro Tests}

Around the world, extracts from approximately 55 plant species belonging to 26 families have already been evaluated against $R$. (B.) microplus. In some species, active compounds with insecticide and/or acaricide activity have been identified, but only a few substances have so far been proven to be active against $R$. (B.) microplus (Table 1). Brazil is a tropical country, with continental dimensions and the highest biodiversity on the planet. Studies on the efficacy of native or naturalized plants against $R$. (B.) microplus have been rapidly expanding in this country, and the main results observed will be shown here.

The two species of Meliaceae most investigated against R. (B.) microplus are Melia azedarach and Azadirachta indica (neem). Preliminary investigations on $M$. azedarach showed that the oily hexanic extract obtained from ripe fruits affected reproduction on engorged females (BORGES et al., 1994). More recently, studying some ripe fruit extracts, Borges et al. (2003) observed a higher larval mortality in chloroformic extracts (100\%) and hexanic extracts $(98 \%)$ than in ethanolic extracts $(50 \%)$, at concentration after $0.25 \%$. Similarly, hexanic and chloroformic extracts produced a greater inhibition on females reproductive efficiency (100 and 91.5\%, respectively) than did ethanolic extracts (46\%). Sousa et al. (2008) showed that extracts from green fruits were 1.5 times more efficient than extracts from ripe fruits. However, lower efficiency was obtained by Vivan (2005). Aqueous and hexanic extracts obtained from leaves and fruits and tested at 0.025 to $0.2 \%$ concentration inhibited reproductive efficiency by 1.1 to $47.54 \%$.

Low interference with reproductive efficiency (32\%) was obtained by Costa et al. (2008) using a hydroalcoholic leaf extract from $A$. indica at $20 \%$ concentration. In two studies conducted by Broglio-Micheletti et al. (2009, 2010), extracts and commercial products based on $A$. indica were tested. Hexanic extracts from seeds and ethanolic extracts from leaves at a concentration of $2 \%$ had efficacy of 38.4 and $2.3 \%$, respectively, on females reproduction (BROGLIO-MICHELETTI et al., 2009). The efficiency of commercial formulations of hexanic and alcoholic extracts from seeds at a concentration of $2 \%$ has been found to range from 17 to $73 \%$, with higher efficiency from hexanic extracts (BROGLIO-MICHELETTI et al., 2010).

Various species of the genus Cymbopogon (Poaceae) have also been tested against $R$. (B.) microplus. The essential oil of Cymbopogon winterianus Jowitt was tested against larvae and engorged females. Total inhibition of eclosion was observed at a concentration of $7.14 \%$ and of egg conversion at $10 \%$. All the larvae died at concentrations between 5.5 and $7.14 \%$. The principal components of the essential oil, i.e. citronellal, geraniol and citronellol, were tested against females, and the best results were observed for the first two components. However, activity remained inferior to obtained from the entire essential oil (MARTINS, 2006). The essential oil of Cymbopogon nardus caused $79 \%$ inhibition of reproduction at a concentration of $1 \%$ (OLIVO et al., 2008). On the other hand, Costa et al. (2008) observed that this plant had low efficacy (17\%) against females using a hydroalcoholic extract from leaves at a concentration of $20 \%$. Alcoholic leaf extract of Cymbopogon citratus at a concentration of $2 \%$ had efficacy of $18.35 \%$ against engorged females (BROGLIO-MICHELETTI et al., 2009)

The essential oils of Eucalyptus citriodora and Eucalyptus staigeriana Myrtaceae killed $100 \%$ of the larvae at a concentration of $10 \%$, while Eucalyptus globulus had the same efficacy but at twice the concentration. Against engorged females, the maximum efficacy was observed at a concentration of $25 \%$ for E. citriodora, $10 \%$ for E. globulus and 15\% for E. staigeriana. When the essential oils were formulated as concentrate emulsions, the effect was strengthened (CHAGAS et al., 2002). The hydroalcoholic extract of leaves of Eucalyptus sp had efficacy of $96 \%$ against engorged females at a concentration of $10 \%$ (COSTA et al., 2008). From the same family, Broglio-Micheletti et al. (2009) tested the alcoholic extract of flowers of Syzygium malaccensis at a concentration of $2 \%$ and observed that the rate of interference with the engorged females reproduction was $59 \%$.

The essential oil from leaves of Hesperozygis ringens (Lamiaceae) was tested at 0.625 to $50 \mu \mathrm{L} \cdot \mathrm{mL}^{-1}$ concentration $(\approx 0.0625$ to $5 \%)$ inhibiting oviposition by 11.5 to $76.4 \%$ with $95 \%$ inhibition of larval hatchability at the highest concentration. Those concentrations were all lethal for $100 \%$ of larvae. Pulegone was the main compound isolated from the essential oil (RIBEIRO et al., 2010). In addition, tests on this family were carried out using the essential oil from leaves 
Table 1. Natural products tested against Rhipicephalus (Boophilus) microplus and active compounds with acaricidal or insecticidal activity.

\begin{tabular}{|c|c|c|}
\hline Family & Plant tested against $R$. microplus (Reference) & Natural products with acaricidal or insecticidal activity \\
\hline Asteraceae & Calea serrata Less. (RIBEIRO et al., 2008a) & \\
\hline Acanthaceae & $\begin{array}{l}\text { Rhinacanthus nasutus (L.) Kurz } \\
\text { (KAMARAJ et al., 2010) }\end{array}$ & \\
\hline Amaranthaceae & Achyranthes aspera L. (ZAHIR et al., 2009) & \\
\hline Anacardiaceae & Mangifera indica L. (SRIVASTAVA et al., 2008) & \\
\hline \multirow[t]{2}{*}{ Annonaceae } & $\begin{array}{l}\text { Annona squamosa L. (MAGADUM et al., 2009; } \\
\text { CHUNGSAMARNYART et al., 1990, 1991a) }\end{array}$ & $\begin{array}{l}\text { Squamocin (KAWAZU et al., 1989) } \\
\text { Acetogenins (HOPP et al., 1998) } \\
\text { Annotemoyin-1 (PARVIN et al., 2003) } \\
\end{array}$ \\
\hline & $\begin{array}{l}\text { Annona muricata L. } \\
\text { (CHUNGSAMARNYART et al., 1991b; } \\
\text { BROGLIO-MICHELETTI et al., 2009) }\end{array}$ & $\begin{array}{l}\text { Goniothalamicin (ALKOFAHI et al., 1987) } \\
\text { Gigantetrocin A, annomontacin, bullatalicin (ALALI et al., 1998) } \\
\text { Squamocin (GUADAÑO et al., 2000) }\end{array}$ \\
\hline Caesalpiniaceae & Cassia auriculata L. (KAMARAJ et al., 2010) & \\
\hline Clusicaceae & $\begin{array}{l}\text { Hypericum polyanthemum Klotzsch } \\
\text { (RIBEIRO et al., 2007) }\end{array}$ & \\
\hline Combretaceae & Terminalia chebula Retz. (KAMARAJ et al., 2010) & \\
\hline Ebenaceae & $\begin{array}{l}\text { Diospyros anisandra S. F. Blake } \\
\text { (ROSADO-AGUILAR et al., 2008) }\end{array}$ & \\
\hline Euphorbiaceae & Ricinus communis L. (ZAHIR et al., 2009) & \\
\hline \multirow[t]{4}{*}{ Lamiaceae } & Hyptis verticillata Jacq. (FACEY et al., 2005) & Cadina-4,10(15)-dien-3-one (PORTER et al., 1995) \\
\hline & $\begin{array}{l}\text { Cunila spicata Benth., Cunila microcephala Benth, } \\
\text { Cunila angustifolia Benth (APEL et al., 2009) } \\
\end{array}$ & $\begin{array}{l}\alpha \text {-pinene, } \beta \text {-pinene, sabinene, menthofuran } \\
\text { and 1,8-cineole (APEL et al., 2009*) }\end{array}$ \\
\hline & $\begin{array}{l}\text { Anisomeles malabarica (L.) R. Br. } \\
\text { (ZAHIR et al., 2009) }\end{array}$ & \\
\hline & Hesperozygis ringens Benth. (RIBEIRO et al., 2010) & \\
\hline Lauraceae & $\begin{array}{l}\text { Cinnamomum zeylanicum Blume } \\
\text { (ÁLVAREZ et al., 2008) }\end{array}$ & \\
\hline \multirow[t]{3}{*}{ Leguminosae } & $\begin{array}{l}\text { Dahlstedtia pentaphylla (Taub) Burk. } \\
\text { (PEREIRA; FAMADAS, 2004) }\end{array}$ & \\
\hline & \begin{tabular}{|l} 
Tamarindus indicus L. (CHUNGSAMARNYART; \\
JANSAWAN, 2001, MAGADUM et al. 2009) \\
\end{tabular} & $\begin{array}{l}\text { Oxalic, malic, succinic, citric and tartaric acids } \\
\text { (CHUNGSAMARNYART; JANSAWAN, 2001*) }\end{array}$ \\
\hline & $\begin{array}{l}\text { Copaifera reticulata Ducke } \\
\text { (FERNANDES; FREITAS, 2007) } \\
\end{array}$ & \\
\hline \multirow[t]{2}{*}{ Liliaceae } & Allium sativum L. (MAGADUM et al., 2009) & Lectins (BANDYOPADHYAY et al., 2001) \\
\hline & Gloriosa superba L. (ZAHIR et al., 2009) & \\
\hline \multirow[t]{2}{*}{ Meliaceae } & $\begin{array}{l}\text { Azadirachta indica A. Juss. (WILLIAMS, 1993; } \\
\text { VALENTE et al., 2007; SRIVASTAVA et al., 2008; } \\
\text { COSTA et al., 2008; MAGADUM et al. 2009; } \\
\text { BROGLIO-MICHELETTI et al., 2009, 2010) } \\
\end{array}$ & $\begin{array}{l}\text { Azadirachtin (BUTTERWORTH; MORGAN, 1971) } \\
\text { Salanin (MEISNER et al., 1981) } \\
\text { Nimbin, nimbinin (SIDDIQUI et al., 1988) } \\
\text { Meliatetraolenone, odoratone (SIDDIQUI et al., 2003) }\end{array}$ \\
\hline & $\begin{array}{l}\text { Melia azedarach L. (BORGES et al., 1994, 2003; } \\
\text { VIVAN, 2005; SOUSA et al., 2008). }\end{array}$ & $\begin{array}{l}\text { Azedarachol (NAKATANI et al., 1985) } \\
\text { Trichilins, azedarachins (NAKATANI et al., 1995) } \\
\text { Meliacarpins (BOHNENSTENGEL et al., 1999) } \\
\text { Azadirachtin (MORGAN; THORNTON, 1973) }\end{array}$ \\
\hline \multirow[t]{5}{*}{ Myrtaceae } & Psidium guajava L. (ZAHIR et al., 2009) & \\
\hline & \begin{tabular}{|l} 
Pimenta dioica (L.) Merr. (BROWN et al., 1998) \\
\end{tabular} & Eugenol, methyleugenol (BROWN et al., 1998*) \\
\hline & $\begin{array}{l}\text { Eucalyptus globulus Labill. (CHAGAS et al., 2002; } \\
\text { MAGADUM et al., 2009) }\end{array}$ & Terpenoids, $\delta$-phenothrin, pyrethrum (YANG et al., 2004) \\
\hline & $\begin{array}{l}\text { Eucalyptus staigeriana F. Muell., Eucalyptus citriodora } \\
\text { Hook. (CHAGAS et al., 2002) }\end{array}$ & \\
\hline & $\begin{array}{l}\text { Syzygium malaccensis (L.) Merr. \& Perry } \\
\text { (BROGLIO-MICHELETTI et al., 2009) } \\
\end{array}$ & \\
\hline Moraceae & Artocarpus altilis Park. (WILLIAMS, 1993) & \\
\hline \multirow[t]{3}{*}{ Piperaceae } & Piper aduncum L. (SILVA et al., 2009) & Dill apiol (BERNARD et al., 1995; SILVA et al., 2009*) \\
\hline & $\begin{array}{l}\text { Piper mikanianum (Kunth) Steud., Piper xylosteoides } \\
\text { (Kunth) Steud., Piper amalago L. } \\
\text { (FERRAZ et al., 2010) } \\
\end{array}$ & $\begin{array}{l}\text { Phenylpropanoids, monoterpene and sesquiterpene hydrocarbons } \\
\text { (FERRAZ et al., 2010)* }\end{array}$ \\
\hline & Piper nigrum L. (ÁLVAREZ et al., 2008) & Piperine, pellitorine, pipercide (MIYAKADO et al., 1979) \\
\hline
\end{tabular}

*tested against $R$. (B.) microplus. 
Table 1. Continued...

\begin{tabular}{|c|c|c|}
\hline Family & Plant tested against $R$. microplus (Reference) & Natural products with acaricidal or insecticidal activity \\
\hline Phytolaccaceae & $\begin{array}{l}\text { Petiveria alliacea } \mathrm{L} . \\
\text { (ROSADO-AGUILAR et al., 2010) }\end{array}$ & Dibenzyl trisulfide (JOHNSON et al., 1997) \\
\hline \multirow[t]{4}{*}{ Poaceae } & $\begin{array}{l}\text { Melinis minutiflora P. Beauv. } \\
\text { (HERNÁNDEZ et al., 1989; PRATES et al., 1993) }\end{array}$ & $\begin{array}{l}\text { 1,8-cineole, citronellol, } \alpha \text { and } \beta \text { pinene, linalool, isopinocamphone } \\
\text { and camphor (PRATES et al., } 1998^{*} \text { ) }\end{array}$ \\
\hline & $\begin{array}{l}\text { Cymbopogon winterianus Jowitt } \\
\text { (SRIVASTAVA et al., 1988; MARTINS, 2006; } \\
\text { MARTINS; GONZALEZ, 2007) } \\
\end{array}$ & Citronellal, geraniol, citronellol (MARTINS, 2006*) \\
\hline & $\begin{array}{l}\text { Cymbopogon citratus (D.C.) Stapf } \\
\text { (CHUNGSAMARNYART; JIWAJINDA, 1992; } \\
\text { HEIMERDINGER et al., 2006; BROGLIO- } \\
\text { MICHELETTI et al., 2009) }\end{array}$ & \\
\hline & $\begin{array}{l}\text { Cymbopogon nardus (L.) Rendle } \\
\text { (CHUNGSAMARNYART; JIWAJINDA, 1992; } \\
\text { OLIVO et al., 2008; COSTA et al., 2008) } \\
\end{array}$ & \\
\hline Rosaceae & Prunus persica L. Bastsch (SRIVASTAVA et al., 2008) & \\
\hline \multirow[t]{2}{*}{ Rutaceae } & $\begin{array}{l}\text { Citrus maxima Merr., Citrus reticulata Blanco., } \\
\text { Citrus suncris L., Citrus sinensis L., Citrus hystrix DC } \\
\text { (CHUNGSAMARNYART; JANSAWAN, 1996) }\end{array}$ & d (+)-limonene (CHUNGSAMARNYART; JANSAWAN, 1996*) \\
\hline & Citrus leminum (Risso.) (MAGADUM et al., 2009) & \\
\hline Sapindaceae & $\begin{array}{l}\text { Magonia pubescens A.St. Hil. } \\
\text { (FERNANDES et al., 2008) }\end{array}$ & \\
\hline \multirow[t]{5}{*}{ Solanaceae } & Solanum trilobatum L. (ZAHIR et al., 2009) & \\
\hline & $\begin{array}{l}\text { Withania somnifera (L.) Dunal } \\
\text { (MAGADUM et al., 2009) }\end{array}$ & \\
\hline & $\begin{array}{l}\text { Nicotiana tabacum L. (MAGADUM et al., 2009; } \\
\text { OLIVO et al., 2009) }\end{array}$ & \\
\hline & Solanum torvum Sw. (KAMARAJ et al., 2010) & \\
\hline & Withania somnifera Dun. (MAGADUM et al., 2009) & \\
\hline Verbenaceae & Vitex negundo L. (KAMARAJ et al., 2010) & \\
\hline Winteraceae & Drimys brasiliensis Miers (RIBEIRO et al., 2008b) & $\begin{array}{l}\text { Sesquiterpenoids, cyclocolorenone, bicyclogermacrene and alpha- } \\
\text { gurjunene (RIBEIRO et al., 2008b). }\end{array}$ \\
\hline
\end{tabular}

*tested against $R$. (B.) microplus.

of five Cunila species at concentrations of 2.5, 5 and $10 \mu \mathrm{L} \cdot \mathrm{mL}^{-1}$ $(\approx 0.25,0.5$ and $1 \%)$. C. angustifolia and C. incana caused $100 \%$ mortality of larvae at the lowest concentration and C. spicata at a concentration of $5 \mu \mathrm{L} \cdot \mathrm{mL}^{-1}$. C. incisa and C. microcephala had insignificant action against larvae. The main compounds found in these plants were $\alpha$-pinene, $\beta$-pinene, sabinene, menthofuran and 1,8-cineole (APEL et al., 2009).

Pereira and Famadas (2004) evaluated the action of the ethanolic root extract of Dahlstedtia pentaphylla (Leguminosae) against two strains of tick: one acaricide-sensitive Mozo strain, and one from the field. The plant was less efficient against the field strain. The efficiency was close to $100 \%$ at a concentration of $20 \%: \mathrm{LC}_{50} 1: 34.94 \mathrm{~mL}(\approx 2.86 \%)$ against engorged females and $1: 231.337 \mathrm{~mL}(\approx 0.43 \%)$ against larvae. The $\mathrm{LC}_{50}$ and $\mathrm{LC}_{99}$ of the oleoresinous extract of Copaifera reticulata (Leguminosae) against larvae were $1.579 \mathrm{ppm}(\approx 0.16 \%)$ and $3.491 \mathrm{ppm}(\approx 0.35 \%)$, respectively (FERNANDES; FREITAS, 2007).

Hexanic, ethyl acetate and ethanolic extracts from leaves of Piper aduncum (Piperaceae) were tested against engorged females in increasing, double concentrations from 5 to $100 \mathrm{mg} \cdot \mathrm{mL}^{-1}$ $(\approx 0.5$ to $10 \%)$. For all extracts, even at the highest concentration, the reproductive control was no higher than $62 \%$. Larvae mortality was evaluated at concentrations of 1 to $20 \mathrm{mg} \cdot \mathrm{mL}^{-1}(\approx 0.1$ to $2 \%)$, and was found to be $70.42,40.5$ and $17.2 \%$ in the hexanic, ethanolic and ethyl acetate extracts, respectively, at the highest concentration. Hydrodistillation of the hexanic extract produced $6.8 \%$ essential oil, $94.84 \%$ consisting on the sesquiterpene dill apiol, which caused $100 \%$ larval mortality at $0.1 \mathrm{mg} \cdot \mathrm{mL}^{-1}(\approx 0.01 \%)$ (SILVA et al., 2009). The essential oil of Piper mikanianum (LC $_{50}$ $2.33 \mu \mathrm{L} . \mathrm{mL}^{-1} ; \approx 0.233 \%$ ) was more active against larvae than that of Piper xylosteoides $\left(\mathrm{LC}_{50} 6.15 \mu \mathrm{L} \cdot \mathrm{mL}^{-1} ; \approx 0.615 \%\right.$ ), while the oil of Piper amalago was inactive. The main compounds were phenylpropanoids, monoterpenes and sesquiterpene hydrocarbons (FERRAZ et al., 2010).

Hexanic and methanolic extracts from stems and leaves of Hypericum polyanthemum (Clusiaceae) were tested at concentrations of 6.25 to $50 \mathrm{mg} \cdot \mathrm{mL}^{-1}(\approx 0.625$ to $5 \%)$. The effect against engorged females was low $(19.2 \%)$ at the highest concentration of the hexanic extract, but on other hand, it killed all larvae in all concentrations (RIBEIRO et al., 2007). Similar effects were observed with the hexanic extracts of stems and leaves of Calea serrata (Asteraceae) at the same concentrations (RIBEIRO et al., 2008a).

The $\mathrm{LC}_{50}$ and $\mathrm{LC}_{99}$ of the ethanolic extracts of stems of Magonia pubescens (Sapindaceae) were 365 ppm $(\approx 0.036 \%)$ 
and 4,000 ppm $(\approx 0.4 \%)$ against larvae (FERNANDES et al., 2008). Over $95 \%$ larvae mortality was obtained with the essential oil of Drimys brasiliensis (Winteraceae) at concentrations of 3.125 to $25 \mu \mathrm{L} \cdot \mathrm{mL}^{-1}$ ( $\approx 0.3125$ to $2.5 \%$ ). The oil was characterized by sesquiterpenoids, cyclocolorenone, bicyclogermacrene and alpha-gurjunene (RIBEIRO et al., 2008b). The ethanolic extract of seeds of Annona muricata L. (Annonaceae) at a concentration of $2 \%$ had $100 \%$ efficacy against engorged females (BROGLIOMICHELETTI et al., 2009).

\section{In Vivo Tests}

Although a high number of plant extracts have been tested against $R$. (B.) microplus in laboratory tests, only some of them have also been evaluated on tick infested animals in order to validate the results obtained.

The essential oil of $C$. winterianus was evaluated in two treatments: one through application of the crude oil on the animal's back and the other through aspersion of a solution oil-alcohol (1:10). A significant difference in the number of females was observed between the treated groups, 22 to 28 days after treatment (5.3 to 14.4 and 2.8 to 11.3 in the crude oil and aspersion groups, respectively), and the control group (13.5 to 21.5) (MARTINS; GONZÁLEZ, 2007)

The hexanic extract of ripe fruits of $M$. azedarach at $0.25 \%$ was tested by Borges et al. (2005). Twenty-one days after the treatment, the average number of engorged females was significantly lower in the treated group (188) than in the control group (247), with efficacy ranging from -1.6 to $63.6 \%$ (average $27.3 \%$ ). Recently, in an attempt to increase the efficacy of the hexanic extract of M. azedarach, Sousa et al. (2010) produced a concentrate emulsion of green fruits that was tested at concentrations of 0.25 and $0.5 \%$. It was observed that the daily efficacy ranged from -46.7 to $82.6 \%$ in the treated group in the $0.25 \%$ group and from -16.6 to $89.0 \%$ in the $0.5 \%$ group. There was greater action against larvae and adults than against nymphs. The efficacy was greater than what was found by Borges et al. (2005), although the egg conversion and hatchability of the ticks did not differ between the two experiments. These in vivo results differed from laboratory test observations (BORGES et al., 1994, 2003, SOUSA et al., 2008), in which it had already been demonstrated that the fruit extracts of $M$. azedarach had higher efficacy against the females reproductive efficiency.

The efficacy of aqueous extracts from $A$. indica was compared with abamectin among artificially infested animals. One kilogram of leaves was mixed with $5 \mathrm{~L}$ of water and sprayed on the animals every week, for four weeks. Another group was treated once with abamectin. Similar tick counts were observed 15 and 30 days after treatment in the two groups: 62.5 and 7.71 in the neem group and 50.5 and 16.0 in the abamectin group, respectively (VALENTE et al., 2007). Srivastava et al. (2008) compared the ethanolic extract of neem seeds at a concentration of $8 \%$ with cypermethrin, on artificially infested animals. The mortality in the neem group was $70.5 \%$, five days after the treatment and, in the cypermethrin group, $92.4 \%$, three days after the treatment. Considering the reproductive efficiency of surviving ticks, the efficacy was 68.32 and $80.48 \%$ for the neem and cypermethrin groups, respectively. Similar results were observed by Magadum et al. (2009), also using neem seeds at the same concentration as Srivastava et al (2008).

Pereira and Famadas (2006) tested the root extract of D. pentaphylla at concentrations of $1: 10$ and $1: 20 \mathrm{~mL}$, on artificially infested bovines. The highest efficacies were observed on the third and seventh days after treatment, reaching $76 \%$ in the group treated with the lowest concentration. The reproductive parameters of treated females were not affected by this extract.

Studies conducted by Olivo et al. (2009) evaluated the action of four increasing concentrations (1.25 to 5\%) of an aqueous extract of Nicotiana tabacum on naturally infested animals. The efficacies ranged from $62 \%$ at a concentration of $5 \%$ in the first week up to $77.5 \%, 14$ days after treatment, at the lowest concentration.

\section{Difficulties Relating to the Use of Plant Extracts}

The lost of efficiency of plant extracts when tested on the animals is undoubtedly a hindrance to development of alternative acaricides. This problem reflects the difficulty in controlling plant extracts, because of the high number of chemical compounds present (EVANS, 1996). It needs to be added that natural products show low persistence in the environment, because of degradation caused by daylight, temperature, $\mathrm{pH}$ and microbial action (MULLA; SU, 1999). However, if the complexity of components and multiple action modes may be a obstacle for using of plant extracts, on other hand the development of resistance is retarded (MULLA; SU, 1999; MAGADUM et al., 2009).

Differences relating to edaphoclimatic conditions and the cultivation and conservation of plant materials for extract production may imply oscillations of the results (HEIMERDINGER et al., 2006). Storage of $M$. azedarach fruits for five months at room temperature caused a decrease in their acaricide effect (SOUSA et al., 2008). Yakkundi et al. (1995) observed a 5\% reduction in azadirachtin after one month of storage of $A$. indica seeds and $35 \%$ after four months. Likewise, Johnson et al. (1996) observed a decrease in azadirachtin and salanin after storage for six months.

Even though the synthesis of chemical compounds is determined by the genetic characteristics of the plant, edaphoclimatic factors also interfere with this factor (LAPA et al., 1999). Thus, the chemical composition of plant extracts varies according to the origin of the plant. Such indications were observed for $M$. azedarach as distinct compounds, when observed in fruits coming from different parts of the world (MORGAN; THORNTON, 1973; ARIAS; HIRSCHMANN, 1988; CABRAL et al., 1996). In unpublished results regarding action against $R$. (B.) microplus females in particular, Sousa observed varying efficacies when comparing $M$. azedarach extracts obtained from different regions of Goiás and Mato Grosso, Brazil. High efficacies ranging from 86.8 to $100 \%$ against reproductive efficiency were observed from five out of the eight extracts tested. Intermediate efficacy (41.8 and 51.2\%) was obtained from two extracts and one extract had no effect. 


\section{Final Remarks}

The use of plant extracts to control ticks, especially $R$. (B.) microplus, seems to be a viable alternative, given the enormous number of plants with activity against this tick that have already been found. However, difficulty in transposing the efficacy obtained from the laboratory to the field is one of the main obstacles to their use.

With the aim of surmounting this barrier, multidisciplinary efforts are clearly needed in order to find solutions. Formulations to protect the active compounds from environmental degradation and to enable fast penetration into the tick are necessary. There is the need to conduct pharmacokinetic investigations in order to ensure that standard extracts are used. Studies on soil, climate and cultivation, with the aim of achieving homogenous plants with regard to the presence of active compounds, are desirable. Moreover, toxicological studies to identify risks to human and animal health clearly cannot be neglected.

However, it needs to be borne in mind that the market for plant-based acaricidal products is extremely promising, especially if the high levels of synthetic acaricide consumption are considered. These alternative products for controlling cattle ticks not only would be usable for organic cattle farming but also would form an alternative for controlling resistant strains. Low contamination of food and the environment is also a worldwide desire. Thus, it is essential to invest in developing a pharmaceutical phytotherapy industry, with interdisciplinary approaches towards finding solutions for this important current topic.

\section{References}

ALALI, F. Q. et al. Annonaceous acetogenins as natural pesticides: potent toxicity against insecticide-susceptible and -resistant German cockroaches (Dictyoptera: Blattellidae). Journal of Economic Entomology, v. 91, n. 3, p. 641-649, 1998.

ALKOFAHI, A. et al. Goniothalamicin and annonacin: Bioactive acetogenins from Goniothalamus giganteus (Annonaceae). Cellular and Molecular Life Sciences, v. 44, n. 1, p. 83-85, 1987. PMid:3350126. http://dx.doi.org/10.1007/BF01960258

ÁLVAREZ, V. et al. Control in vitro de garrapatas (Boophilus microplus; Acari: Ixodidae) mediante extractos vegetales. Revista de Biologia Tropical, v. 56, n. 1, p. 291-302, 2008. PMid:18624244.

APEL, M. A. et al. Chemical composition and toxicity of the essential oils from Cunila species (Lamiaceae) on the cattle tick Rhipicephalus (Boophilus) microplus. Parasitology Research, v. 105, n. 3, p. 863-868, 2009. PMid:19421776. http://dx.doi.org/10.1007/s00436-009-1455-4

ARIAS, A. R.; HIRSCHMANN, C. S. The effects of Melia azedarach on Triatoma infestans bugs. Fitoterapia, v. 59, n. 2, p. 148-149, 1988.

BALANDRIN, M. F. et al. Natural plant chemicals: sources of industrial and medicinal materials. Science, v. 228, n. 4704, p. 1154-1160, 1985. PMid:3890182. http://dx.doi.org/10.1126/science.3890182

BANDYOPADHYAY, S.; ROY, A.; DAS, S. Binding of garlic (Allium sativum) leaf lectin to the gut receptors of homopteran pests is correlated to its insecticidal activity. Plant Science, v. 161, n. 5, p. 1025-1033, 2001. http://dx.doi.org/10.1016/S0168-9452(01)00507-6
BERNARD, C. B. et al. Insecticidal defenses of Piperaceae from the Neotropics. Journal of Chemical Ecology, v. 21, n. 6, p. 801-814, 1995. http://dx.doi.org/10.1007/BF02033462

BOHNENSTENGEL, F. I. et al. Insecticidal meliacarpins (C-seco limonoids) from Melia azedarach. Phytochemistry, v. 50, n. 6, p. 977-982, 1999. http://dx.doi.org/10.1016/S0031-9422(98)00644-X

BORGES, L. M. F. et al. In vitro efficacy of extracts of Melia azedarach against the tick Boophilus microplus. Medical and Veterinary Entomology, v. 17, n. 2, p. 228-231, 2003.

BORGES, L. M. F. et al. Ação do extrato hexânico de frutos maduros de Melia azedarach (Meliaceae) sobre Boophilus microplus (Acari: Ixodidae) em bezerros infestados artificialmente. Revista de Patologia Tropical, v. 34, n. 1, p. 53-59, 2005.

BORGES, L. M. F.; SILVA, A. C.; NEVES, B. P. Teste “in vitro” de eficácia do cinamomo (Melia azedarach, L) sobre fêmeas ingurgitadas do Boophilus microplus, Can. (Acari: Ixodidae). Revista de Patologia Tropical, v. 23, n. 2, p. 175-179, 1994.

BROGLIO-MICHELETTI, S. M. F. et al. Extratos de plantas no controle de Rhipicephalus (Boophilus) microplus (Canestrini, 1887) (Acari: Ixodidae) em laboratório. Revista Brasileira de Parasitologia Veterinária, v. 18, n. 4, p. 44-48, 2009.

BROGLIO-MICHELETTI, S. M. F. et al. Ação de extrato e óleo de nim no controle de Rhipicephalus (Boophilus) microplus (Canestrini, 1887) (Acari: Ixodidae) em laboratório. Revista Brasileira de Parasitologia Veterinária, v. 19, n. 1, p. 46-50, 2010.

BROWN, H. A. et al. Biological activities of the extracts and constituents of pimento, Pimenta dioica L. against the Southern cattle tick, Boophilus microplus. Insect Science and its Application. v. 18, n. 1, p. 9-16, 1998.

BUTTERWORTH, J. H.; MORGAN, E. D. Investigation of the locust feeding inhibition of the seeds of the neem tree, Azadirachta indica. Journal of Insect Physiology, v. 17, n. 6, p. 969-977, 1971. http://dx.doi.org/10.1016/0022-1910(71)90002-3

CABRAL, M. M. O. et al. Anti-moulting activity in Brazilian Melia azedarach. Memórias do Instituto Oswaldo Cruz, v. 91, n. 1, p. 117-118, 1996. http://dx.doi.org/10.1590/S0074-02761996000100021

CHAGAS, A. C. S. et al. Efeito acaricida de óleos essenciais e concentrados emulsionáveis de Eucalyptus spp. em Boophilus microplus. Brazilian Journal of Veterinary Research and Animal Science, v. 39, n. 5, p. 247-253, 2002. http://dx.doi.org/10.1590/S1413-95962002000500006

CHAGAS, A. C. S. et al. Sensibilidade do carrapato Boophilus microplus a solventes. Ciência Rural, v. 33, n. 1, p. 109-114, 2003. http://dx.doi. org/10.1590/S0103-84782003000100017

CHUNGSAMARNYART, N. et al. Practical extraction of sugar apple seeds against tropical cattle ticks. Kasetsart Journal (Natural Science Supplement), v. 25, p. 101-105, 1991a.

CHUNGSAMARNYART, N.; JANSAWAN, W. Acaricidal activity of peel oil of Citrus spp. on Boophilus microplus. Kasetsart Journal (Natural Science), v. 30, p. 112-117, 1996.

CHUNGSAMARNYART, N.; JANSAWAN, W. Effect of Tamarindus indicus L. against the Boophilus microplus. Kasetsart Journal (Natural Science), v. 35, p. 34-39, 2001.

CHUNGSAMARNYART, N.; JIWAJINDA, S. Acaricidal activity of volatile oil from lemon and citronella grasses on tropical cattle ticks. Kasetsart Journal (Natural Science), v. 26, p. 46-51, 1992.

CHUNGSAMARNYART, N.; JIWAJINDA, S.; JANSAWAN, W. Effects of plant crude-extracts on the cattle tick (Boophilus microplus) 
insecticidal action I. Kasetsart Journal (Natural Science Supplement), v. 24, p. 28-31, 1990.

CHUNGSAMARNYART, N.; JIWAJINDA, S.; JANSAWAN, W. Acaricidal effect of plant crude-extracts on tropical cattle tick (Boophilus microplus). Kasetsart Journal (Natural Science Supplement ), v. 25, p. $90-100,1991 b$.

COSTA, F. B. et al. Eficácia de fitoterápicos em fêmeas ingurgitadas de Boophilus microplus, provenientes da mesorregiấo oeste do Maranhão, Brasil. Revista Brasileira de Parasitologia Veterinária, v. 17, supl. 1, p. 83-86, 2008.

EVANS, W. C. The plant and animal kingdoms as sources of drugs. In: SAUNDERS, W. B. Trease and evans pharmacognosy. London, 1996. p. $15-17$.

FACEY, P. C. et al. Biological activity and chemical composition of the essential oil from Jamaican Hyptis verticillata Jacq. Journal of Agricultural Food Chemistry, v. 53, n. 12, p. 4774-4777, 2005. PMid:15941314. http://dx.doi.org/10.1021/jf050008y

FERNANDES, F. F.; BESSA, P. A. D.; FREITAS, E. P. S. Evaluation of activity of the crude ethanolic extract of Magonia pubescens St. Hil (Sapindaceae) against larvae of the cattle tick Rhipicephalus (Boophilus) microplus (Canestrini, 1887) (Acari: Ixodidae). Brazilian Archives of Biology and Technology, v. 51, n. 6, p. 1147-1152, 2008. http://dx.doi. org/10.1590/S1516-89132008000600009

FERNANDES, F. F.; FREITAS, E. P. S. Acaricidal activity of oleoresinous extract from Copaifera reticulata (Leguminosae: Caesalpinioideae) against larvae of the southern cattle tick, Rhipicephalus (Boophilus) microplus (Acari: Ixodidae). Veterinary Parasitology, v. 147, n. 1-2, p. 150-154, 2007. PMid:17478043. http://dx.doi.org/10.1016/j.vetpar.2007.02.035

FERRAZ, A. B. F. et al. Acaricidal activity and chemical composition of the essential oil from three Piper species. Parasitology Research, v. 107, n. 1, p. 243-248, 2010. PMid:20428889. http://dx.doi.org/10.1007/ s00436-010-1878-y

FOOD AND AGRICULTURE ORGANIZATION OF THE UNITED NATIONS - FAO. Module 1. Ticks: acaricide resistance: diagnosis management and prevention. In: FOOD AND AGRICULTURE ORGANIZATION OF THE UNITED NATIONS - FAO. Guidelines resistance management and integrated parasite control in ruminants. Rome: FAO Animal Production and Health Division, 2004.

GUADAÑO, A. et al. Insecticidal and mutagenic evaluation of two annonaceous acetogenins. Journal of Natural Products, v. 63, n. 6, p. 773-776, 2000. http://dx.doi.org/10.1021/np990328+

HEIMERDINGER, A. et al. Extrato alcoólico de capim-cidreira (Cymbopogon citratus) no controle do Boophilus microplus em bovinos. Revista Brasileira de Parasitologia Veterinária, v. 15, n. 1, p. 37-39, 2006.

HERNÁNDEZ, L.; PARRA, D.; AHUMADA, A. Actividad repelente y acaricida del aceite y algunas fracciones cromatograficas del pasto Melinis minutiflora frente al Boophilus microplus. Revista Colombiana de Ciencias Quimico Farmaceuticas, n. 17, p. 45-50, 1989.

HOPP, D. C. et al. Three new bioactive bis-adjacent THF-ring acetogenins from the bark of Annona squamosa. Bioorganic \& Medicinal Chemistry, v. 6, n. 5, p. 569-575, 1998. http://dx.doi.org/10.1016/ S0968-0896(98)00018-2

JOHNSON, L.; WILLIAMS, L. A. D.; ROBERTS, E. V. An insecticidal and acaricidal polysulfide metabolite from the roots of Petiveria alliacea. Pesticide Science, v. 50, n. 3, p. 228-232, 1997. http://dx.doi.org/10.1002/ (SICI)1096-9063(199707)50:3\%3C228::AID-PS575\%3E3.0.CO;2-J
JOHNSON, S.; MORGAN, E. D.; PEIRIS, C. N. Development of the major triterpenoids and oil in the fruit and seeds of neem (Azadirachta indica). Annals of Botany, v. 78, p. 383-388, 1996. http://dx.doi. org/10.1006/anbo.1996.0133

JONSSON, N. N.; PIPER, E. K. Integrated control programs for ticks on cattle. Queensaland: The University of Queensland, 2007. 163 p.

KAMARAJ, C. et al. Evaluation of medicinal plant extracts against bloodsucking parasites. Parasitology Research, v. 106, n. 6, p. 1403-1412, 2010. PMid:20306205. http://dx.doi.org/10.1007/s00436-010-1816-z

KAWAZU, K.; ALCANTARA, J. P.; KOBAYASHI, A. Isolation and structure of neoannonin a novel insecticidal compound-from the seeds of Annona squamosa. Agricultural Biological Chemistry, v. 53, n. 10, p. 2719-2722, 1989.

LAPA, A. J. et al. Farmacologia e toxicologia de produtos naturais. In: SIMÓES, C. M. et al. Farmacognosia: da planta ao medicamento. Porto Alegre: UFRGS, 1999. p. 181-196.

MAGADUM, S.; MONDAL, D. B.; GHOSH, S. Comparative efficacy of Annona squamosa and Azadirachta indica extracts against Boophilus microplus Izatnagar isolate. Parasitology Research, v. 105, n. 4, p. 1085-1091, 2009.

MARTINS, J. R. S.; FURLONG, J.; LEITE, R. C. Controle de carrapatos. In: BARROS-BATTESTI, D. M. B.; ARZUA, M.; BECHARA, G. H. (Org). Carrapatos de importância médico-veterinário da Regiáo Neotropical. Um guia ilustrado para identificação de espécies. São Paulo: Instituto Butantam, 2006. p. 145-153.

MARTINS, R. M. Estudio in vitro de la acción acaricida del aceite esencial de la gramínea citronela de Java (Cymbopogon winterianus Jowitt) em la garrapata Boophilus microplus. Revista Brasileira de Plantas Medicinais, v. 8, n. 2, p. 71-78, 2006.

MARTINS, R. M.; GONZÁLEZ, F. H. D. Uso del aceite de citronela de Java (Cymbopogon winterianus Jowitt) (Panicoidideae) como acaricida frente a la garrapata Boophilus microplus Canestrini (Acari: Ixodidae). Revista Brasileira de Plantas Medicinais, v. 9, n. 4, p. 1-8, 2007.

MEISNER, J. et al. Response of Spodoptera littoralis (Boisd.) and Earias insulana (Boisd.) larvae to azadirachtin and salannin. Phytoparasitica, v. 9, n. 1, p. 27-32, 1981. http://dx.doi.org/10.1007/BF03158326

MIYAKADO, M. et al. The Piperaceae Amides I: Structure of Pipercide, a new insecticidal Amide from Piper nigrum L. Agriculture and Biological Chemistry, v. 43, n. 7, p. 1609-1611, 1979.

MORGAN, E. D.; THORNTON, M. D. Azadirachtin in the fruit of Melia azedarach. Phytochemistry, v. 12, n. 2, p. 391-392, 1973. http://dx.doi.org/10.1016/0031-9422(73)80025-1

MULLA, M. S.; SU, T. Activity and biological effects of neem products against arthropods of medical and veterinary importance. Journal of American Mosquito Control Association, v. 15, n. 2, p. 133-152, 1999.

NAKATANI, M. et al. Azedarachol, a steroid ester antifeedant from Melia azedarach var. Japonica. Phytochemistry, v. 24, n. 9, p. 1945-1948, 1985. http://dx.doi.org/10.1016/S0031-9422(00)83097-6

NAKATANI, M. et al. Thee new antifeeding meliacarpinins from chinese Melia azedarach Linn. Tetrahedron, v. 51, n. 43, p. 11731-11736, 1995. http://dx.doi.org/10.1016/0040-4020(95)00724-M

OLIVO, C. J. et al. Óleo de citronela no controle do carrapato de bovinos. Ciência Rural, v. 38, n. 2, p. 406-410, 2008. http://dx.doi.org/10.1590/ S0103-84782008000200018 
OLIVO, C. J. et al. Extrato aquoso de fumo em corda no controle do carrapato de bovinos. Ciência Rural, v. 39, n. 4, p. 1131-1135, 2009. http://dx.doi.org/10.1590/S0103-84782009000400026

PARVIN, S. et al. Pesticidal activity of pure compound annotemoyin-1 Isolated from chloroform extract of the plant Annona squamosa Linn. against Tribolium castaneum (Herbst) (Coleoptera: Tenebrionidae). Pakistan Journal of Biological Sciences, v. 6, n. 12, p. 1088-1091, 2003.

PEREIRA, J. R.; FAMADAS, K. M. Avaliação "in vitro" da eficiência do extrato da raiz do timbó (Dahlstedtia pentaphylla) (Leguminosae, Papilionoidae, Millettiedae) sobre Boophilus microplus (Canestrini, 1887) na regiáo do Vale do Paraíba, São Paulo, Brasil. Arquivos do Instituto Biológico, v. 71, n. 4, p. 443-450, 2004.

PEREIRA, J. R.; FAMADAS, K. M. The efficiency of extracts of Dahlstedtia pentaphylla (Leguminosae, Papilionoidae, Millettiedae) on Boophilus microplus (Canestrini, 1887) in artificially infested bovines. Veterinary Parasitology, v. 142, n. 1-2, p. 192-195, 2006. PMid:16904267. http://dx.doi.org/10.1016/j.vetpar.2006.06.034

PORTER, R. B. R. et al. Acaricidal and insecticidal activities of cadina-4, 10 (15)-dien-3-one. Phytochemistry, n. 40, v. 3, p. 735-738, 1995. http://dx.doi.org/10.1016/0031-9422(95)00338-8

PRATES, H. T. et al. Atividade carrapaticida e composiçáo química do óleo essencial do capim-gordura. Pesquisa Agropecuária Brasileira, v. 28, n. 5, p. 621-625, 1993.

PRATES, H. T. et al. Identification of some chemical components of the essential oil from molasses grass (Melinis minutiflora Beauv.) and their activity against cattle-tick (Boophilus microplus). Journal of Brazilian Chemical Society, v. 9, n. 2, p. 193-197, 1998. http://dx.doi.org/10.1590/ S0103-50531998000200013

RIBEIRO, V. L. S. et al. Acaricidal properties of extracts from the aerial parts of Hypericum polyanthemum on the cattle tick Boophilus microplus. Veterinary Parasitology, v. 147, n. 1-2, p. 199-203, 2007. PMid:17475407. http://dx.doi.org/10.1016/j.vetpar.2007.03.027

RIBEIRO V, L. S. et al. Acaricidal activity of Calea serrata (Asteraceae) on Boophilus microplus and Rhipicephalus sanguineus. Veterinary Parasitology, v. 151, n. $2-4$, p. $351-354,2008$ a.

RIBEIRO, V. L. S. et al. Chemical composition and larvicidal properties of the essential oils from Drimys brasiliensis Miers (Winteraceae) on the cattle tick Rhipicephalus (Boophilus) microplus and the brown dog tick Rhipicephalus sanguineus. Parasitology Research, v. 102, n. 3, p. 531-535, 2008b. PMid:18046578. http://dx.doi.org/10.1007/s00436-007-0799-x

RIBEIRO, V. L. S. et al. Acaricidal properties of the essential oil from Hesperozygis ringens (Lamiaceae) on the cattle tick Rhipicephalus (Boophilus) microplus. Bioresource Technology, v. 101, n. 7, p. 2506-2509, 2010. PMid:19954969. http://dx.doi.org/10.1016/j.biortech.2009.11.016

ROSADO-AGUILAR, J. A. et al. Actividad ixodicida de extractos crudos de Diospyros anisandra contra larvas de Rhipicephalus (Boophilus) microplus (Acari: ixodidae). Tropical and Subtropical Agroecosystems, v. 8, n. 3, p. 297-301, 2008.

ROSADO-AGUILAR, J. A. et al. Acaricidal activity of extracts from Petiveria alliacea (Phytolaccaceae) against the cattle tick, Rhipicephalus (Boophilus) microplus (Acari: ixodidae). Veterinary Parasitology, v. 168, n. 3-4, p. 299-303, 2010. PMid:20042296. http://dx.doi.org/10.1016/j. vetpar.2009.11.022

SIDDIQUI, S. et al. Tetracyclic triterpenoids and their derivatives from Azadirachta indica. Journal of Natural Products, v. 51, n. 1, p. 30-43, 1988. http://dx.doi.org/10.1021/np50055a003
SIDDIQUI, B. S. et al. Tetracyclic triterpenoids from the leaves of Azadiractha indica and their insecticidal activities. Chemical Pharmaceutical Bulletin, v. 51, n. 4, p. 415-417, 2003. http://dx.doi. org/10.1248/cpb.51.415

SILVA, W. C. et al. Toxicity of Piper aduncum L. (Piperales: Piperaceae) from the Amazon forest for the cattle tick Rhipicephalus (Boophilus) microplus (Acari:Ixodidae). Veterinary Parasitology, v. 164, n.2-4, p. 267-274, 2009. PMid:19573994. http://dx.doi.org/10.1016/j. vetpar.2009.06.006

SONENSHINE, D.E. Biology of ticks. New York: Oxford University, 1993. $465 \mathrm{p}$.

SOUSA, L. A. D et al. Avaliação da eficácia de extratos oleosos de frutos verdes e maduros de cinamomo (Melia azedarach) sobre Rhipicephalus (Boophilus) microplus (Acari: Ixodidae). Revista Brasileira de Parasitologia Veterinária, v. 17, n. 1, p. 36-40, 2008

SOUSA L. A. D. et al. Potential synergistic effect of Melia azedarach fruit extract and Beauveria bassiana in the control of Rhipicephalus (Boophilus) microplus (Acari: Ixodidae) in cattle infestations. Veterinary Parasitology, v. 175, n. 3-4, p. 320-324, 2011. PMid:21055878. http://dx.doi.org/10.1016/j.vetpar.2010.10.012

SRIVASTAVA, R. et al. Efficacy of Azadirachta indica extracts against Boophilus microplus. Parasitology Research, v. 104, n. 1, p. 149-153, 2008. PMid:18769940. http://dx.doi.org/10.1007/s00436-008-1173-3

VALENTE, M.; BARRANCO, A.; SELLAIVE-VILLAROEL, A. B. Eficácia do extrato aquoso de Azadirachta indica no controle de Boophilus microplus em bovino. Arquivo Brasileiro de Medicina Veterinária e Zootecnia, v. 59, n. 5, p. 1341-1343, 2007. http://dx.doi.org/10.1590/ S0102-09352007000500039

VIEIRA, L. S; CAVALCANTE, A. C. R. Resistência anti-helmíntica em rebanhos caprinos no Estado do Ceará. Pesquisa Veterinária Brasileira, v. 19, n. 3-4, p. 99-103, 1999. http://dx.doi.org/10.1590/S0100736X1999000300002

VIVAN, M. P. Uso do cinamomo (Melia azedarach) como alternativa aos agroquímicos no controle do carrapato bovino (Boophilus microplus). 2005. 72 f. Dissertaçáo (Mestrado)-Universidade Federal de Santa Catarina, Florianópolis.

WALKER, A. R. et al. Ticks of Domestic Animals in Africa: A guide to identification of species. Edinburgh: University of Edinburgh, 2003.

WILLIAMS, L. A. D. Adverse effects of extracts of Artocarpus altilis Park and Azadirachta indica (A. Juss) on the reproductive physiology of the adult female tick, Boophilus (Canest.), Invertebrate Reproduction and Development, v. 23, n. 2-3, p. 159-164, 1993. http://dx.doi.org/10.108 0/07924259.1993.9672307

YAKKUNDI, S. R.; THEJAVATHI, R.; RAVINDRANATH, B. Variation of Azadirachtin content during growth and storage of neem (Azadirachta indica) seeds. Journal of Agricultural and Food Chemistry, v. 43, n. 9 , p. 2517-2519, 1995. http://dx.doi.org/10.1021/jf00057a036

YANG, Y. C. et al. Ovicidal and adulticidal activity of Eucalyptus globulus leaf oil terpenoids against Pediculus humanus capitis (Anoplura:Pediculidae). Journal of Agricultural and Food Chemistry, v. 52, n. 9, p. 2507-2511, 2004. PMid:15113148. http://dx.doi.org/10.1021/jf0354803

ZAHIR, A. A. et al. Laboratory determination of efficacy of indigenous plant extracts for parasites control. Parasitology Research, v. 105, n. 2, p. 453-461, 2009. PMid:19308453. http://dx.doi.org/10.1007/s00436$009-1405-1$ 